\title{
Do constraints rather than freedom provide more opportunities for language learners?
}

Vishnu S Rai

\begin{abstract}
The paper reports the findings of a small scale research which tried to find out what happens when students do creative writing. Two tasks, one having more constraints and the other having more freedom were given to the learners. Interestingly it was found that the task which had more constraints was found to be more interesting to the learners.
\end{abstract}

Key words: affective engagement, creative writing, experimental research,

\section{Introduction}

Language learning is facilitated by affective engagement (Arnold, 1999) and creative writing tasks foster it with fun and playfulness. Creative writing provides the learners with new ways to play with the language and as they play more with the language, they learn more. It is said that as learners are engaged to manipulate the language in interesting and demanding ways attempting to express uniquely personal meanings, they necessarily engage with the language at a deeper level of processing than with expository texts (Rai, 2008). The importance of playfulness in L1 can hardly be exaggerated (Cook, 2000). The more a child plays with the language the more he learns and the more he learns the language the more he plays with it. The other important thing about creative writing is that it encourages learners to take risks (Maley and Mukundan 2008) and as a result the learners are able to create novel sentences. However, this playfulness, this encouragement for taking risks which helps creativity is not 'the absence of constraints, but their imaginative -yet disciplined -development.'(Boden2001).
In order to see if these claims made by the supporters of creative writing are true, the researcher conducted a mini research. The present paper is the report of that experimental research.

\section{Objectives}

The objectives of this small scale research were to find out

- If creative writing really engages the learners in language learning

- If constraints rather than freedom provide more opportunities for the learners to play with the language

- How do learners do the task (The process they go through)?

- If they produce novel sentences (The quality of the language they produce.)

\section{Tools for data collection}

Two tasks were given to the subjects. They had to write two types of poems:

(a) Acrostics and (b) Simile. They were asked to do the tasks in pairs. 
Task 1: Write Acrostic poems on any two of the given titles: HOLIDAY, TEACHER, BOOK.

Rules: Each line must start with the letter of the title word.

The whole poem must be related to the title word.

Example: JOY

1.

$$
2 .
$$

3.

Jump Just thinking

Jovial and

Out of Of

Outstanding feeling in

Your sorrow You Your life

Task 2: Write two simile poems. The first lines for the poems are given.

1. My teacher is like

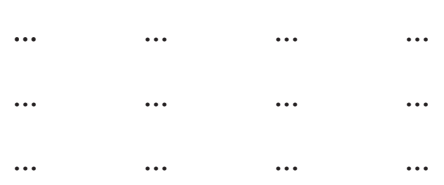

2. My friend is like...

$\begin{array}{lll} & \ldots & \ldots\end{array}$

$\begin{array}{llll} & \cdots & \cdots & \\ & & & \end{array}$

$\begin{array}{llll}\ldots & \ldots & \ldots & \ldots\end{array}$

Compare your teacher and friend with any one of the following: mountain, rock, river, flower (any flower), lake, sea, tree -anything from nature.

In addition to the tasks, post-writing interviews were conducted with the participants. The participants were the students of M.Ed. with major English. However, they have never been taught creative writing.

Two groups of boys and girls participated in this experiment. The researcher explained the tasks and the purpose to the participants. Boys and girls did the same tasks separately. They were asked to talk together while doing the task which was recorded and later analysed. After they finished the task, the researcher talked informally with them about the experiment.

\section{The products}

It is interesting to see the products of the tasks but the process is even more interesting. Because of the space limitation, all the recordings are not included here. Only two one for acrostic and the other for simile from each group (boys and girls) are shown here. They are very similar and the only difference is that girls have also used Nepali in doing the tasks whereas boys did not use Nepali -they used English throughout their discussion. This was most probably because they thought that they, being the students of Master level with major English should not use any other language than English although the researcher had explicitly told them that they could also speak in their native language. The recordings given her is from a pair of boys Sagun Shrestha and Ramesh Ghimire.

\section{The products}

\section{Acrostics:}

\section{BOOK}

Body of knowledge

Organised systematically

Oriented towards

Knowing the vagueness of the world

\section{HOLIDAY}

Hunger of

leisure

In the

Dim of business

As the ox in the yolk

(Note: *spelling mistake)

\section{Similes}

Our teacher is like a rose

Smiling amongst the thorns

Teaching the knowledge of struggle and hardship

And spreading the perfume of love from the Pandora's box. 
Our friend is like an orange

Who wants create the ocean of juice

For the sake of human beings

In the world of starvation

\section{The process}

Following is the recording of the discussion between Sagun and Ganesh while they were doing the tasks which shows the process or the type of thinking. The recording is the discussion for HOLIDAY and the dots "..." represent the pause in their speech.

Sagun: Holiday. We should link with romance.

Ramesh: Romance, nature... somehow, OK? Holiday. (coughs) H... H... means what possible words can be that is related to Holiday? H...

Sagun: Havock... Havock but it does not make sense.

Ramesh: H...

Sagun: See? Hungry Of Leisure... Holiday.

Ramesh: Yea, Hungry Of Leisure...

Sagun: Hungry Of Leisure.

Ramesh: hun-hun.

Sagun: Holiday.

Ramesh: Yea, yea, yea, Holiday... Hungry Of Leisure -Hungry is somehow related to describe the person, yea? So, hunger... Holiday. Yes H... H... Holiday... OK.

Sagun: Hunger Of Leisure.

Ramesh: Leisure... Hunger Of Leisure... Hunger Of Leisure in... ... Hunger Of Leisure

Sagun: Let's start with such a phrase with such a word that touches heart

Ramesh: Yea, yea.

Sagun: Hunger Of Leisure in...

Ramesh: OK, let's... Happy also possible... yea happy?

Sagun: You mean that is...
Ramesh: Happy... O... Happy. O... Out of books, O... Out of the classroom, no? I think the...

the boy is very much bored with his reading, no... reading in the classroom... Out of the classroom. L... leisure... L for leisure aan... .......

Sagun: Holiday!

Ramesh: Leisure... aan... ... Leisure, Love... other possible... that's I... I means (coughs) ...

what?... What have you written?

Sagun: let's... (paper shuffling) Hunger Of Leisure In Dim of business...

Ramesh: Leisure... In Dim of business... What's there for business... what's...?

Sagun: Yes business... business

Ramesh: Business? What's there connection... Leisure

Sagun: Business... $\quad \ldots \quad$ as... OK? Yoke, yoke... What's in Nepali जुवा Hunger Of Leisure In

Dim of business As the ox in the Yoke.

Ramesh: Then, then, the description should match Holiday. Let's try once. Hunger Of Leisure...

Sagun: Holiday means, we are always hungry for leisure?

Ramesh: Ye a...

Sagun: In Dim of business... when you are in... in... see?

Ramesh: Yea.

Sagun: Bag of... ... As the ox in the Yoke.

Ramesh: Hunger Of Leisure!

Sagun: It's literary sense.

Ramesh: Literary sense, yea. Hunger Of Leisure... Now, Hunger Of Leisure... Holiday.

Somehow the... acrostics, no? It's acrostics, no? So it describes Hunger Of Leisure -Holiday. I think it describes the person, yea? Holiday, Hunger Of Leisure In Dim of business As the ox in the... Yok. 
Hunger of Leisure.

Sagun: It states Holiday -what's Holiday. Holiday

is... Holiday is Hunger of Leisure.

Ramesh: Hunger of Leisure.

Sagun: Hunger Of Leisure... not a person... he is not hungry for leisure...

Ramesh: hun-hun.

Sagun: But Holiday is Hunger Of Leisure.

Ramesh: Yea-yea

Sagun: In the Dim of business As the ox in the yolk.

Ramesh: Ok, OK. That's right.

Sagun: It makes sense?

Ramesh: Yea-yea. Now let's try another one, simile.

Following is the recording of the discussion for writing simile: "My teacher is like..."

Ramesh: We have to compare out teacher one of the words over here... simile!

Sagun: I think...

Ramesh: My teacher is like... we have to compare out teacher with the nature, yea? Tree,

flower... which one is the best to describe our teacher... to compare our teacher with tree, flower, lake, sea

Sagun: Let's try to... (paper shuffling) isn't...

Ramesh: Now, tree, flower, for example any flower... rose, jasmine, etc., lake, river, stone,

mountain, fruit anyone word related to nature.

Sagun: Rock or any other word related to nature, I think better compare with rose.

Ramesh: Ye...s

Sagun: Like, my teacher is like a red-red rose (laughter). My teacher is like a rose... who

blooms... who blooms amongst... amongst the thorns

Ramesh: un-hun

Sagun: Yea, My teacher is like a rose, who blooms amongst the thorns... and gives the

fragrance, scent...

Ramesh: un-hun, that's also right... we can compare with mountain as well

Sagun: OK. Let's compare

Ramesh: My teacher is like... like the mountain which smiles to us teaching the lesson of

boldness... boldness and the greatness... so we can compare...

Sagun: With mountain as well?

Ramesh: And other... river... what about the lake and the river... rock

Sagun: My teacher is like... like a lake who is very silent and patient

Ramesh: hun-hun

Sagun: It lies a gigantic body of knowledge

Ramesh: We can compare him with the... the river if we follow.. aan the changing... what?

Sagun: The changing nature of...

Ramesh: It means timely changing nature, no?

Sagun: Yea.

Ramesh: For example, we have one philosophy pragmatism and instrumentalism always

change... there is nothing constant... change according to time... change is life... this way we can compare him with river too... OK, let's do with river. My teacher is like a river

Sagun: OK.

Ramesh: Who always flows... grasps the tide of time Sagun: Yea...

Ramesh: Yea? Tides of time and... teaches the same lesson... and OK, let's start writing, OK?

Sagun: Which one? (paper shuffling)

Ramesh: First with river then with rose or any other Sagun: My teacher is like a river

Ramesh: Like a river... like a river full stop. Let's 
make my teacher is like a river.

Sagun: Or we can... ... ... My teacher is like a river who...

Ramesh: Yea he... he... he can change... he can change

Sagun: With tides of time

Ramesh: Yea, tide of time

Sagun: My teacher is like a river, he can change with the tide of time

Ramesh: Tide of time...

Sagun: With the gigantic body of knowledge

Ramesh: OK, write, write. (paper shuffling)

Sagun: With a gigantic body of knowledge...

Ramesh: Like a river he can change with tide of time with the gigantic body of knowledge... ...

Sagun: See, we have to link once again with the river, right?

Ramesh: Yea.

Sagun: What does... OK, what's the actual behavior of river... see the natural behavior... it flows

Ramesh: Yea.

Sagun: Does it have any destination?

Ramesh: It doesn't have... it it doesn't have any destination... it means, does it... does it stop for

a while or does it want to have some rest?

Sagun: No.

Ramesh: No?

Sagun: It doesn't want to rest as well.

Ramesh: No? It always flows means... now

Sagun: My teacher is like a river, he can change with tides of time as gigantic body of knowledge

Ramesh: And flows... let's make with flows.. and flows a...

Sagun: And flows... ... the highest body of knowledge of the world
Ramesh: And flows... OK, sounds also possible... and flows... ... may be... ... yea...

knowledge...

Sagun: Let's make with rose, OK?

Rames: Now.. My teacher is like a rose...

Sagun: My teacher is like a rose... Smiling amongst the thorns... amongst the thorns... teaching

the lesson

Ramesh: Can we say Keeping the fragrance of knowledge, OK?

Sagun: Or we can say also, Teaching the lesson of struggle and hardship

Ramesh: OK, that's fine... teaching the...

Sagun: Lesson of struggle and hardship

Ramesh: Yea, struggle and hardship... My teacher is like a rose Smiling amongst the thorns

Teaching the knowledge of struggle and hardship (both)... and spreading the perfume of... spreading the perfume of what?

Sagun: Spreading the perfume of ...

Ramesh: Perfume of love

Sagun: from the... ... of his heart (laughter) See for the first time positive things.. (narration of a

story of Pandora's box) spreading the perfume of love from the Pandora's box.

Ramesh: Pandora's box, OK.

Sagun: It's true.

Ramesh: Yea, should we try the next one?

It is interesting to see the products by the girl group and the processes they went through. They were

three in number: Arhul Kumari Sah, Vijayalaxmi Awasthi and Gomati Awasthi.

\section{The products}

Acrostics:

TEACHER

HOLIDAY

Tactful

Happy 


$\begin{array}{ll}\text { Enthusiastic } & \text { Occasion } \\ \text { Active } & \text { Lovely } \\ \text { Charmful* }^{*} & \text { Interest } \\ \text { Honest } & \text { Dynamic } \\ \text { Eager } & \text { Activity } \\ \text { Regular } & \text { Yummy }\end{array}$

\section{Similes:}

1.

My teacher is like a river

Which follows forever

Without caring ups and dons

Having a lot of hopes and dream.

2.

My friend is like a tree

Which gives me shadow

Remains with me

In happiness and sorrow

\section{The process}

These are the transcription of the recordings of the girl participant discussion for writing the acrostic TEACHER and the simile "My teacher is like..."

A: (paper shuffling) One is from acrostic and next is from simile and in acrostics we have to

choose two words.

B: Two words.

A: It will be better to TEACHER and BOOK.

B: OK, TEACHER and BOOK. For you what's better?

C: What's... what's... BOOK and... HOLIDAY

A: Teacher has also (laughter) teaching... teaching efficiency in subject matter aan many words,

you know.............

B: We can also use Book, B for BOOK.

A: I am very interested to TEACHER
B: TEACHER? OK, let's take teacher... an... Target

C: No, no there is full form of teacher (all three talking together unintelligibly)

B: aan the full form but we have to make our own extra yea have to make our...

A: Yea, yea

(All three) TEACHER.

A: Talen... Talented in subject matter.

B: Talented? No.

C: Subject, what?

$\mathrm{B}$ : But $\mathrm{S}$ is not here.

A: T Talented

B: No, we can...

A: $T$ the first letter

B: First letter (all three) OK, first...

A: Subject matter

C: Enthusiastic

A: Enthusiastic, Active, Charmful

B: Charmf... $\quad \ldots \quad$ Honest

A: Honest... and Efficiency in subject matter -that is also suitable... efficiency

C: Efficiency in subject matter

A: अनि Resource person

B: Resor...

A: Resource person, OK?

B: Recording also (all three talking together unintelligibly) he has to record... ...

C: OK, then TEACHER and HOLIDAY

B: HOLIDAY.

A: Yea, OK, HOLIDAY.

B: HOLIDAY, HOLIDAY, OK.

A: If you are interested in HOLIDAY...

B: (laughs) HOLIDAY aan OK. 
A: In comparison of BOOK, HOLIDAY is more interesting...

B: Let's take interesting one.

C: First, what should we... I write, TEACHER?

B: No, first... first... We should try TEACHER.

A: Technique or Tactful

B: OK, Tactful

A: Tactful

C: I have to write complete sentence like Tactful in subject matter?

B: Yea.

A: Yea.

B: Because there is also (all three talking together unintelligibly)

A: We can write that... no, no right...

C: Actually what I thought was we can write, OK Tactful.

A: Tactful

B: Just write key words.

A: Key word Tact... Tactful in which tact...

C: Tactful?

B: Tactful.

A: OK, OK, Tactful

C: Tactful, then?

A: Enthu si...

B: Enthusiastic, yea

A: Enthusiastic... spelling (laughter)

B: T H U S

A: T H U S I A S

B: S I A S T I C, yes.

A: Enthusiastic and A Active

B: Active, yea.

A: Charmful C
B: Charming, Charming

A: Charmf

B: Charming, yea Charming is better

C: What, what I write Charming or

B: Charming. Charmful is...

A: Charming in that teacher and teacher is charmful

B: (in a very low voice) Teacher is very charmful person (laughter). What is charm..

A: Charming and charmful is different

C: Charm...

A: Charming and charmful is different.

B: But, no. Different but charming, charming in between (all three talking together unintelligibly) OK, let's write...

A: We are going to write the qualities of the teacher... ... that's why teacher should be charmful.

B: Charming also (all three talking together unintelligibly). OK, Charming, Charming.

A: I think Charmful

C: We can write another... two columns, make two columns

A: aan Charmful अनि $\mathrm{H} . . . \mathrm{H}$

B: Honest

A: Honest... ‥ E, E, E Eager or Efficie

A: Efficienc..y, Efficiency, Efficient in subject matter, may be we can write key... Efficient in subject matter

$\mathrm{B}$ : Eager is also good, yes?

C: Yes, Eager is also good.

A: Eager to teach... Eager... Eagerness... Eager or Eagerness... if we write aam noun then we have to write adjectives too.

C: Then, what should I write... Earning (laughter) they are earning money.

A: In comparison of money, teacher is earning prestige.

B: Nowadays teacher (laughter) what should we 
need, we need money

C: Yea.

B: Earning, nowadays teachers are earning a lot because they are taking tuition also. (laughter)

C: Yea.

B: So, Earning is, then, you know...

A: No, Yea... aam... we at

C: Efficient?

A: We have to write the good qualities of teacher.

B: (laughs) OK. Earning is also... without earning what can we do?

A: Efficient...

C: What? What? Eager or Efficient or...

A: Efficient in subject matter, I think Enthusiastic...

B: Extraordinary

A: Extra..ordi...

C: Many teachers are not extraordinary (laughter) some teachers are ordidnary...

B: All teachers are not enthusiastic and active

A: Efficient in subject matter

B: Extraordinary in subject matter

C: Yea, that also- Extraordinary aan...

A: Extra knowledge?

B: Extra knowledge? Yea, that would be quite good

A: Extra may be Efficient, may be Eager, may be...

B: Eager, Eager is also

A: Quality?

B: Efficiency

A: It is better if we write ... we are talking of all teachers (laughter).. aan so it is

B: O my god!

C: It is because, you know, our teacher, bad quality of students (laughter)
A: Efficient in subject matter, I think Efficient in subject matter or there is Efficiency in teacher

B: Effi... Effective

A: Efficiency in a teacher of Efficient in subject matter

C: Effective is also OK but what Effective?

A: Effecti...

B: Effective

A: Effective, yea, yea, OK... Effective, Effective... $\quad . . \quad \quad$... If we write key words, then it has lots of meaning Efficient in subject matter, Effective in subject matter and aan Eager to teach

B: Effective

C: But I haven't...

B: OK, Efficiency in subject matter -are you satisfied?...

A: If he or she is a good teacher, trained teacher then he or she should, must be $\mathrm{E}$ E Efficient in

subject matter otherwise we have kicked out from the classroom (laughter)... ...we will also be kicked out by our students if we don't have in subject matter, efficient in subject matter. I... why are you... (Laughter)

B: Because... OK, OK Eager to learn, Eager to teach

C: Eager to do anything

A: Eager to get knowledge?

B: Knowledge?... Eager to give knowledge, Eager to give you knowledge

A: Eager to share knowledge

B: Eager to share, Eager is the better word...

C: then, Resource person? Or what should I...

A: Resource person, OK.

B: Or Regular

C: Regular?

A: Resource of knowledge, Resource of knowledge, 
yes? Resource of knowledge

B: Resource person.. ... it doesn't

match, OK. If we write it becomes longer because we

have to write, you know words that can rhyme, no?

C: Regular?

B: Regular.

A: Regular, yea.

B: Regular, OK.

\section{Simile}

Following is the recording of the discussion carried out by the girls for writing simile.

B: OK, now let's think of simile.

C: Simile. My teacher is like...

B: Like flower? My teacher is...

C: No.o.o. (laugh) like...

A: There is one quotation in English "Guru is a bulb he gives light and lights his flowers.'

C: Gurus is...

A: That is in Nepali. गुरू बत्तीजस्तै हुन्छ : आफू पनि बल्छ र अरूलाई पनि बल्न सिकाउँछ।

B: But we have another saying in Hindi, गुरू गुड होत है, चे ला शक्कर होता है (laughter) क्या क्या बन जाता है।

A: On the basis of that quotation we can generate here one.

C: OK, what do we...

B: My teacher is like a flower...

C: aan... flower, stone mountain

B: I don't like stone mountain

C: My teacher is like a river who always, no, flows

A: Yea, may be, may be aan may be like flower too...

C: Flower too?

A: Yea, or river

B: I think river is...
A: If he is river, then he can... in... ... mis

B: What?

A: river भ पनि यताउतिको छाललाई पनि बगाएर लान्छ नि सिंगै, है ?

B: पख्नु, यताबाट पनि अभौ... Ice चाहिं not good one... aan... fruit is not good, rose?

A: Rose? Rose मिल्छ ?

B: OK, what about my teacher is like a tree who gives shade

$\mathrm{C}:$ Where is tree?

$\mathrm{B}$ : It is there.

C: O, yea.

B: My teacher is like a tree

A: Yea, may be (laughter)

B: My teacher is like a tree and I am like a bee (laughter)

C: My teacher is like a tree, मतलब...

A: Teacher like a tree!

B: We'd have a lot of words from tree, we can take a lot of... yea

A: We can get shadow

B: We can get shade also and we can get wood also.

C: But yea, river, river also... teacher is like a river that he can do lot of aan...

A: Think about second line, third line if we have... we have to finish

$\mathrm{C}$ : My teacher is like a river... river

B: If first... first

A: if our techer is like a flower, then there is no benefits (laughter)

B: What benefit (laughter) se... scent

A: Only smell... can spray smell and we can also spray that smell in our world (laughter)

C: If teacher is flower... it's so difficult to ... scent...

A: That can be for our friend, lover, or beloved 
(laughter)

B: My teacher is like aan... my teacher like a river

A: Rose, jasmine

$\mathrm{B}$ : My teacher is like a river

A: River, stone... ice no, sand no

C: My teacher is like a river -river which never... tired

A: Ok, Ok

$\mathrm{B}$ : My teacher is like a river, next line, next line should be similar...

C: No, it's necessary.

$\mathrm{B}$ : OK, then, my teacher is like a river who is never tired...

C: My teacher is like a river

A: Who never stops

B: Never stops, never tired... we don't have to, OK? We have to make our

C: Think words... make strong

B: OK, then

A: Quality of a river is what? Always flows, flows or blows, flows down to swallow to what?

उकालो ओरालो (laughter) उकालो-ओरालो होइन ? जसरी माया हाम्रो उकालो-ओरालो, ठूलोबाट स्यानोतिर बग्छ नि- कहिले स्यानोबाट ठूलोतिर बगेको हेर्नुभा छ ? माया भन्ने चीज होइन ? प्रकृतिले मात्र मायालाई ठूलोबाट स्यानोतिर बग्न सिकाया छ कि त्यसैले river पनि उकालोबाट ओरालोतिर बग्छ, हैन ? हाम्रो teacher पनि हामीभन्दा senior हुन्छ नि त ! त्यो teacher को माया हामी विद्यार्थीमा river जस्तै बग्छ, के !

B: Ok, OK. (laughter)

C: We can write like this: My teacher is like a tree who gives shadow to us, OK?

B: OK, who gives shadow to us

A: मलाई त tree भन्दा river मनपई ।

C: Who gives us life to live in the world... or who gives, gives... makes the environment green,

and you know that we can write, we can add other things also.
B: What... My teacher is like a tree, who gives shadow to us... which or who? We can...

C: OK then... Or we can describe we are leaves of the tree

B: Yea, yea

C: Yes?

B: Yea, yea.

A: Teacher is bran... tree and we are branches of that -we students are branches of that

B: Yea, but we have to choose -we don't have to choose all words- one word

$\mathrm{C}$ : I think river is better for teacher and tree is better for friend

A: Y..e..a... My teacher is a river who never tired...... (laughter) My teacher is a river who

never tired... where love is always shared from senior to junior...

B: No, that's not, that's not

C: My teacher is a river which flows, which flows in any season, yes which flows in any season

with lots of...

A: With lots of...

B: With lots of hopes and beliefs (all three talk together unintelligibly) With lots of hopes and

beliefs -that's better

A: Who can adjust lots of

B: OK, My teacher

$\mathrm{C}:$ Dreams?

B: Yes, dreams also

A: What should be the last sentence? (paper shuffling)

B: My teacher is like a river, Who flows for ever, With lots of hopes and dreams

C: My teacher is like a river, Who flows or which

A: Who may be

C: But... river, which flows 
B: May be which...

C: OK, which flows for ever... ups and downs because

B: yea

C: We don't see ups and downs

B: My teacher is like a river, which flows for ever, without seeing ups and downs, with lots of

hopes and dreams

A: Without watching

B: No

A: Without caring?

B: O yea... what?

C: Without caring ups and downs

B: My teacher is like a river which flows for ever without caring ups and downs

A: Ups and downs... यताउता नहेरिकन

B: Yea

C: It's OK -without caring?

B: Without caring ups and downs

C: Having a lots of hopes and dreams

B: Having... having a lot of hopes and dreams

A: Hopes and dreams, yea.

\section{Analysis}

A comparison between the two tasks (data) reveals the following.

\begin{tabular}{|c|c|c|}
\hline & Acrostics & Simile \\
\hline $\begin{array}{l}\text { Prod - } \\
\text { ucts }\end{array}$ & $\begin{array}{l}\text {-More complex } \\
\text { structures } \\
\text {-More novel and } \\
\text { surprising ideas }\end{array}$ & $\begin{array}{l}\text {-Less complex lan- } \\
\text { guage } \\
\text {-No surprising ideas }\end{array}$ \\
\hline Process & $\begin{array}{l}\text {-Lots of repetition, } \\
\text { back and forth, } \\
\text {-More playing } \\
\text { with the language } \\
\text {-Thinking aloud in } \\
\text { case of Ramesh }\end{array}$ & $\begin{array}{l}\text {-Repetitions but less } \\
\text { playing with the lan- } \\
\text { guage } \\
\text {-Less discussion be- } \\
\text { tween the pair }\end{array}$ \\
\hline
\end{tabular}

\begin{tabular}{|c|c|c|}
\hline Time & $\begin{array}{l}\text {-More time taken: } \\
20 \text { minutes }\end{array}$ & $\begin{array}{l}\text {-Less time taken } 15 \\
\text { minutes }\end{array}$ \\
\hline Others & $\begin{array}{l}\text { - acr -Acrostics } \\
\text { create more op- } \\
\text { portunities for L2 } \\
\text { making and L2 } \\
\text { creativity, requir- } \\
\text { ing learners to } \\
\text { construct mean- } \\
\text { ing through L2 } \\
\text { directly } \\
\text { - P a rti i ip a nts } \\
\text { found it more } \\
\text { challenging as } \\
\text { well as interesting }\end{array}$ & $\begin{array}{l}\text {-Participants found } \\
\text { it less challenging } \\
\text { - ex -Excessive L1 } \\
\text { use may hinder } \\
\text { Opp opportunities } \\
\text { for the destabiliza- } \\
\text { tion of learners'L2. }\end{array}$ \\
\hline
\end{tabular}

If we compare the products of the tasks, it is clear that the acrostic poems have far more complex language (particularly of the acrostics written by the boys) than that of the simile ones. Not only that but the comparison also shows that the acrostics have more novel and/ or surprising ideas than those of similes. Particularly, the acrostic HOLIDAY (if we overlook the linguistic mistakes "din" spelt as "dim" and "yoke" spelt as "yolk") has some very novel and surprising ideas expressed in a complex (metaphoric) language which explain holiday as 'hunger for leisure' and people as 'ox in the yolk'. By comparison, simile poems are straightforward in the sense that one can fairly guess what is coming next, e.g. rose presupposes thorns, teaching presupposes knowledge and perfume love.

If we look at the processes (or the thinking) involved in doing the tasks, acrostics took more time to be completed than the similes. The recordings of girls' discussion for writing acrostics (which are not given here) were longer than those of the similes. This also suggests that the participants played more with the language in doing acrostics than in similes and that they ventured to take more risks in inventing and using the language in acrostics which is why they have novel ideas and surprising constructions. 
A comparison between the two types of poem writing also shows that while doing acrostics participants did more chaotic thinking whereas in doing similes they were more straightforward. There were a lot of repetitions, going back and forth and checking the ideas, etc. in acrostics. So their thinking and the discussion were not as systematic and organized as in similes, however eventually they ended with as organized writing in acrostics as in similes.

There are different approaches to creativity viz. the product approach which refers to the characteristics of creative products, the process approach which refers to the thinking involved in creative tasks and the linguistic approach which refers to the language play in the task. They all suggest that acrostic is better than similes which mean constraints rather than freedom helps learners to be more creative.

A comparison between the products of the two groups shows that the acrostics written by boys are more complex both in structure and ideas. In the process, girls discussed more than boys probably because they were three in number and they took more time than boys to finish the task. They had more lively discussion than boys and they played with the language more than their boy classmates. Their discussion also support the view (Tan Bee 2009) that in writing acrostics conceptual systems (ideas) are activated through L2 directly, then translated into L1 and that acrostics create more opportunities for L2 making and L2 creativity, requiring learners to construct meaning through L2 directly. But while doing simile, concepts are first retrieved in L1 then translated into L2 and that excessive L1 use may hinder opportunities for the destabilization of learners'L2.

An informal talk with the participants after they finished the tasks revealed that they found acrostics more interesting although more challenging. They also said that they had never written such constructions as 'Hunger of leisure' or 'Body of knowledge' and obviously they were thrilled with the idea that they could write something like this. They have never heard about creative writing and opined that these kinds of activities are certainly more beneficial than traditional types of activities. When the girls group was asked why they wrote just one word for each letter for acrostic task and not phrases although in their discussion they talked of the phrases, they said that they thought the words were enough to describe the key word.

Most of the discussions in both groups were carried out in English. The girls discussed partly in Nepali when they did the simile task. Boys said that they because the task was in English, they should do the discussion also in English, although it would have been easier to discuss in Nepali. One girl said that because the task was given by their teacher (the researcher) and as they were students of English, they thought it just proper that they should discuss in English and the others agreed what she said. They thought that probably their teacher would not be happy if they did not carry their discussion in English? This was the main reason for them to use English throughout in their discussion but they also said that it was easier to think and discuss in English for the acrostic task.

\section{Nature of tasks}

If we look at the nature of the tasks, we can present it as follows.

Acrostic

$\underline{\text { Simile }}$

$\underline{\text { Rule-based task }}$

Imagination foregrounded

Formal constraint Foregrounds the imaginary situation (imagine A as B)

Semantic constraint

Fore-grounds discourse

(give two reasons)

Acrostic writing has less freedom than simile writing and yet acrostic provides learners with more opportunities to play with the language. Its products are better in terms of novel use of language as well as novel ideas. So, constraints rather than freedom initiate more chaotic and form-oriented thinking and play and scaffold creativity. It supports what Boden (2004) says, 'creative thinking is made possible by constraints'. Creativity does not come from absolute freedom: it's guided by 
internal discipline which the learners or the writer imposes upon them.The experiment shows that acrostics which put more restraints on the learners create more opportunities for L2 making and L2 creativity than similes which have more freedom.

\section{Suggestions for future research}

Better understanding of the processes learners encounter and the language they produce in different play tasks will help teachers to design more effective play tasks. More research is needed to understand the nature of affordances offered by various play tasks.

More investigations are needed which analyse the transcripts of learners' interaction in play tasks and the language they produce as a result of the triadic interaction between the learner(s) and the task.

Vishnu S Rai has over 27 years experience in teaching ELT and in teacher training with the Department of English Language Education, Tribhuvan University, Nepal. As a national consultant, he helped the Ministry of Education, Nepal, develop a new English curriculum, textbooks and teacher training materials. He was also a Master Trainer Facilitator who helped design ToT and training materials for primary school teachers. He has published over a dozen books on ELT and Linguistics and has written several course books. He has also presented papers in national and international seminars and conferences in Asian and European countries. He has lived and worked in Nepal, India and Germany. His professional interests lie in creative writing, research and materials development. He likes reading and travelling. He can be contacted at vpsrai@yahoo.com

\section{References}

Arnold, J. (1999). Affect in language learning. Cambridge: Cambridge University Press.

Boden, M. A. (2000). Crafs, Rerception, and the possibilities of the body. British Journal of Aesthetics. 40:289-301

Boden, M. A. (2004) The creative mind: Myths and mechanism. London: Routledge.

Cook, G. (2000). Language play: Language learning. Oxford: Oxford University Press.

Maley,A. and Mukundan, J. (2008) Empowerment in action: Creative writing by Asian teachers for Asian Learners. Malasiya: Pearson Longman.

Rai, V. S. (2008). Creative writing: the late comer is the winner!. Journal of NELTA, Vol. 13: 102-105.

Tan Bee Tin (2009). What happens when students do creative writing. A paper presented in the $6^{\text {th }}$ Asian English Teachers Creative Writing Workshop. Jakarta, Indonesia. 